\title{
Sustaining the Liveliness of Public Spaces in El Houma through Placemaking. The Case of Algiers
}

\author{
Mohamed Yazid Khemri, Alessandro Melis \\ University of Portsmouth, United Kingdom \\ School of Architecture \\ yazid.khemri@port.ac.uk | alessandro.melis@port.ac.uk
}

Silvio Caputo

University of Kent, United Kingdom

School of Architecture

s.caputo@kent.ac.uk

\begin{abstract}
This paper takes Algiers as a case study, highlighting the social use of urban spaces in El Houma, in the Algerian capital, as a form of placemaking, a people-centred approach aimed at improving urban spaces within a neighbourhood.

El Houma is a word for neighbourhood in North Africa synonymous with Hara and Mahalla in the Middle East. El Houma is not a typical neighbourhood that only houses people, it is a socio-spatial product formed by social relations between residents of the same neighbourhood. It is, therefore, a way of representing urban space though social practices, creating a strong sense of community, a sense of place and social interaction. Based on theories and mapping techniques from urban sociology and urban design, the research applies a methodology of activity mapping, in order to investigate patterns of outdoor social activities in public spaces and their correlation with the physical design of the neighbourhood. The research will measure the liveliness of public spaces exploring how people adapted their lifestyle to the built environment and vice versa. The findings demonstrate how the different social activities are spatially distributed, and their impact on the liveliness of el Houma.
\end{abstract}

Keywords: placemaking, el Houma, social use of urban space, liveliness, Algiers

To cite this article:

Khemri, M. Y., Melis, A., Caputo, S. (2020). Sustaining the Liveliness of Public Spaces in El Houma through Placemaking. The Case of Algiers, The Journal of Public Space, 5(I), I29-152, DOI I0.3289I/jps.v5il. 1254

This article has been double blind peer reviewed and accepted for publication in The Journal of Public Space.

(c) (-) This work is licensed under a Creative Commons Attribution - Non Commercial 4.0 International License https://creativecommons.org/licenses/by-nc/4.0/ 


\section{Introduction}

Cities are enjoyable places to live when they are designed as meeting places, and provide opportunities for people to socialise and streghten their sense of community. However, at a time of uncontrolled urban growth, cities are rapidly expanding to accommodate the increasing number of people and buildings, ignoring the human scale and needs of people. For example, the proliferation of gated communities and mass housing units are gradually eating up public spaces, leaving little or no space for community activities, and decreasing the opportunity for communities to coalesce (Wang, 2017; Yigitcanlar et al., 20I5).

A city should provide opportunities for walking, cycling and enjoying public life in a safe and comfortable environment; through a human-centered design of streets, spaces and parks, it should increase the presence of people in public spaces, their safety and their liveliness. A human-centred city creates a pleasurable atmosphere for visitors and for those who live, work, and play there. It offers spaces based on human scale that encourage social interaction and social cohesion. Richard Rogers in the foreword of Gehl's book "cities for people" (2010) argues that people should have equal and easy access to public spaces, exactly as they should have to clean water, he also emphasised the importance of socialising, through creating places for sitting, talking, interacting and playing.

It has been widely claimed that liveliness of urban spaces enhances social sustainability within the neighbourhood, through frequent social use of space, which contributes to achieve safety, social interaction, social inclusion, sense of belonging, liveliness to name but a few (Jacobs, 196I; Schipperijn et al., 2010; Worpole and Knox, 2007). Social use of space or life between buildings as Gehl (1987) termed it, refers to outdoor activities, which can be divided into three categories; the first category comprises the necessary activities, which are everyday tasks, like going to work or school, waiting for a bus or shopping etc. The second category regards optional activities like taking a walk to promenade, sitting, standing to watch urban life etc. The third category is about social activities, which are related to the interaction of people in public spaces, like children at play, meetings between people, communal activities, greetings and chatting...

Social activities are the most influenced by both the physical and social environments, whereas the necessary activities are to some extent compulsory and take place throughout the year, under all weather conditions. Conversely, the optional activities only happen when the weather and place are favourable. Social activities can also be termed as resultant activities, as they evolve from the other two categories, so in high quality and inviting public spaces, people tend to stay longer and perform different activities that result in increasing social interaction and social cohesion of the community (Gehl, 20l0). Social activities can also happen in residential streets, parks, near workplaces, corners of streets, public spaces and squares, and between neighbours or people with mutual interests or through a simple contact between unknown people. Several studies condemn the modernism era for rejecting the city as an urban space, where people meet, live, work and play. In developing countries, designing human scale cities is complex and neglected; the reliance on modern approaches in designing cities and the importation of foreign born models, led to lifeless and segregated urban spaces (Ahmed, 2017; Rudlin \& Falk, 1999; Zhang, Yung, \& Chan, 2018).

In order to design socio-culturally appropriate urban spaces, there is a need to understand people's way of life, through observing, mapping and analysing their use of 
urban space, to identify people's aspirations and needs. In a time of rapid urbanisation and population growth, it is estimated that by 2030 , over $70 \%$ of the world populations will be living in urban areas (Komeily \& Srinivasan, 2015); therefore, more efforts should be focused on designing liveable, equitable and socially sustainable neighbourhoods around the world.

Many scholars consider the neighbourhood as the most suitable urban element at which sustainability can be applied in order to create sustainable neighbourhoods, and thus sustainable cities (Marique \& Reiter, 20I I; Sharifi, 2016; Sturgeon, Holden, \& Molina, 2016; Zhang et al., 2018). A neighbourhood comprises a variety of spaces, where each space varies in terms of use and accessibility, within a suitable size for studying and strengthening public life.

This research will investigate the liveliness of a public space within a neighbourhood, demonstrating how different activities occurred in the space according to the characteristics of the space (size, land use, urban furniture, and location). The paper aims to present results of the mapping of social activities in a public space, in order to answer the following questions: what are the types of outdoor social activities? How are these activities spatially distributed? Is there a social logic that informs the spatial distribution of the activities? To what context the different outdoor activities contribute to the liveliness of the place? How do these activities contribute to placemaking? Did the activities enhance the social aspect of the space through liveliness?

This paper takes Algiers as a case study; it will highlight the social use of urban spaces in El Houma, which is a word for neighbourhood in North Africa that is characterised by strong social sustainability. The neighbourhood studied in this paper is considered as a true embodiment of El Houma, a place characterised, as several urban sociologists highlighted, by the presence of strong social relations, social practices and positive lifestyles (Bouaouina, 2007; Dris, 2005; Grangaud, 2009; Icheboudene, 2002). Public spaces are a resource in which political and social movements - including political protest, religious activities, etc. - can take place (Mitchell, 1995). This paper focuses on the public space as a space open to the general public, regardless the age, gender or social class, but it does not extend its analysis to political and antisocial uses.

This paper is divided into 4 sections. Section I is made of two sub-sections, one includes the research background and aims of the paper, and one where the methodology used in the case study is explained. In section 2, the paper conceptualises the concept of the neighbourhood, and provides definitions and explanations of the concept of El Houma. In the following section 3 , the paper sheds light on the literature regarding the correlation between liveliness and placemaking, and their contribution to urban social sustainability. Finally, in section 4, the case study is introduced, analysed and discussion of the findings along with concluding remarks are presented.

\section{Methodology: space-society and mapping}

Mixed methods are particularly useful in urban studies; combining the strengths of different methods will help to achieve better results, instead of the limitations of a single approach (Carmona, 20I5). By using mixed methods, the research will analyse the relationship between the built environment and the social activities occurring in a square of El Houma as an expression of social sustainability and liveliness through unstructured interviews and social activity mapping. Numerous pioneers of research 
and planners have studied public life in urban spaces, in order to provide recommendations to create better neighbourhoods and public spaces, such as Jane Jacobs, William Whyte, and Jan Gehl. This research will build upon their methods and techniques in order to understand the social life of residents in El Houma and identify what spaces respond well to their lifestyle.

This study connects the discipline of urban planning and sociology research methods in order to shed light on the relationship between urban space and social life of Algerians, illustrated through the concept of El Houma. Ethnographic methods of observation will lead to the mapping of social activities and their direct impact on the use of urban spaces. This method is the "snapshot observation", also known as "activity mapping" that has been developed to understand the social life in urban spaces (Francis, 1984) and people's activities in urban spaces (Gehl, 1987; Mahdzar, 2008; Shirazi, 2018). According to Groat and Wang (2002), this technique is considered as an ethnographic approach, because it locates the researcher in the real world with the object of inquiry in order to investigate the social life of residents in its natural setting.

The mapping of social activities will allow a better understanding of the social use of space as a way of placemaking and liveliness contributing to the social sustainability of the area.

The observations of the social activities were conducted in an open public space located in the middle of a neighbourhood, which is attended by many people of different ages and gender. The observation and mapping focused on the different social activities happening in the space, such as chatting, playing, strolling, shopping, eating or drinking outside, resting, jogging, dancing, playing music, participating in community activities (Gehl and Savarre, 20I3), and any other activities that contribute to social sustainability and the liveliness of the neighbourhood. This open mode of data collection will allow to capture spontaneous and unexpected activities.

The observations of the social activities were conducted during the last days of August 2019 , during weekdays and weekends (Friday and Saturday constitute the weekend in Algeria) and at different times of the day, in order to capture the different patterns of social use of space on different days of the week, and the fluctuation of activities during a single day from morning to late afternoon.

The observations and mapping were carried out on many spaces of the neighbourhood, public (open public spaces, main streets), semi-public (secondary streets) and private spaces (residential area or tertiary streets) of El Houma, as part of an ongoing research $(\mathrm{PhD})$. However, for this paper, results that focus on one square will be presented to discuss the social use of urban space as a factor of liveliness in el Houma.

The following section attempts to conceptualise the neighbourhood, which will pave the way towards an understanding of the concept of El Houma

\section{Background paradigms and underlying principles Conceptualising the neighbourhood}

Since antiquity, neighbourhoods held an important part within the fabric of the city, as they spatially formed human settlements and have always been considered the nucleus of community life (Sharifi, 2016; Smith, 2010).

The definition of the neighbourhood could be subjective, whereas it can be dependent on different paramaters, such as the physical design of the place, the availability of 
amenities, the residents's perception of the area, population size and the social relations between residents (Barton 2000). However, most scholars agree that a neighbourhood is formed of two interconnected and important components; its physical design and social aspect.

The physical design of the neighbourhood refers to the spatial and functional aspect that is defined by the built environment and the availability of facilities and services, while the social aspect is an interpetation of the neighbourhood as a community held together by social relations, grouping people around a common identity (Barton, 2000; Briggs, 1997; Choguill, 2008; Forrest \& Kearns, 200I; Galster, 200 I; Hallman, 1984; Jenks \& Dempsey, 2007; Martin, 2003; Meegan \& Mitchell, 200I; Rohe, 2009; Sharifi, 2016; Smith, 2010; Suttles, 1972).

Neighbourhood and community are overlapping and correlated terms, while each one has a different meaning, they can exist only when they are together; the former is the spatial unit that is made of residential or mixed use development, and the latter is the social construct referring to a group of people with shared interests, support and solidarity (Barton, 2000; Jenks \& Dempsey, 2007).

From the early $20^{\text {th }}$ century, several neighbourhood planning theories appeared with the aim to create better and liveable neighbourhoods, the most influential ones started in I 898 when Ebenezer Howard introduced the idea of the Garden City, which stimulated Clarence Perry to develop the Neighbourhood Unit concept in 1923. Subsequently, the Neighbourhood Unit concept was developed further by Clarence Stein and Henry Wright in the planning of Radburn in 1929. From then on, several authors urged planners to opt for a neighbourhood planning that promotes a sense of community and social interaction among residents, like Mumford (1937, 1954), as well as Kevin Lynch, Jane Jacobs and Christopher Alexander in 1960s, who provided recommendations for creating better and liveable neighbourhoods (Fatani, Mohamed, \& Al-Khateeb, 20I7). Lefebvre (1991) claims that urban spaces are material and functional production of a society; they reflect the way of life of residents who interact with the built environment. Their daily activities are informed by local culture, social life, weather and built environment. Hence, the conception, perception and use of urban spaces vary around the world, as each society produces a distinctive social space that meets its social and cultural aspirations and needs (Lefebvre, 1991).

Accordingly, in Algiers, the social activities that happen in urban spaces are translated into a concept called El Houma, which is a traditional form of neighbourhood characterised by strong social relations. Hence, this research takes Algiers as a case study, discussing the social use of urban space as a form of placemaking that contributes to the liveliness of the area.

\section{Neighbourhood in Algiers: El Houma Origin of El Houma}

El Houma (or El Hawma) is a typical expression for a neighbourhood in North Africa that is defined by social realities rather than territorial divisions as the notion of neighbourhood suggests (Dris, 2005; Grangaud, 2013).

El Houma in Algeria is considered a vital part in the city organisation and the lifestyle of people. It is pronounced slightly different around the country, depending on the accent of the region. In the capital, it is pronounced and written "Houma" or "Huma" by the 
residents of Algiers, and both names can be found in many written documents; it is pronounced Hawma in the eastern and western part of the country (Grangaud, 2009). Whilst "El" is the Arabic definite article equal to "the" in English. El Houma is a term peculiar to Maghribi Arabic, and it is only used in North Africa (Dickie, 1994). It is synonymous with Mahalla and Hara in the middle east; it comes from the Arabic word HA-WA-MA which means the environment, a circular perimeter within the eye's purview; it also indicates a density of an area; main part; bulk; main body; a quarter, a section of a city (Wehr, 1976). The verb is HAMA, which connotes to hover, swarm; circle, to go around.

EL Houma is believed to appear in Algiers since the first settlement and evolved since the medieval ages, where a town was constituted of many enclosed quarters occupied by homogenous communities that are formed of people from the same tribe, family, religion, ethnicity or occupation (potters, jewellers, etc) (Abu-Lughod, 1987). The quarters were closely knit groups, where residents shared mutual rights and duties among each other, which increased the sense of common identity, solidarity, sense of community and security. Each Houma was accessed through one or two gates, which were usually closed at night for safety, the gates marked the boundary between the public and private spaces (Abu-Lughod, 1987; Burckhardt, 2009; Von Gruenbaum, 1958). El Houma was a model of sustainable community where every quarter was a mixed-use development to some extent, satisfying the necessary daily needs of residents. Each Houma was equipped with the necessary amenities nearby such as a public bath, a bakery, a place for prayer, local small shops, and sometimes a local market shared between neighbouring quarters (Bouaouina, 2007; Grube, 1978). With the arrival of the ottomans in the $16^{\text {th }}$ century, the city expanded following the same pattern of homogenous communities to what is today known as the Casbah.

\section{El Houma in contemporary time}

A neighbourhood is considered as an expression of El Houma by its inhabitants, only when some aspects of urban social sustainability are present, such as social cohesion, solidarity, trust and sense of belonging etc. These features are a result of sharing life, experiences and events with people within a common place of residence and play. For the individual, El Houma is a social reality as well as a geographic or a spatial one; it is a place where one goes to everyday to play or chat with their playmates, classmates or neighbours who are or have been part of their daily lives for a while creating intricate social ties (Grangaud, 2009). Members of el Houma recognise and support each other in the different events in their life, for instance; when one of them gets married, they invite all the residents of el Houma to share a meal together (Grangaud, 2009). Similarly, when someone dies, people of el Houma gather around their house to show support and solidarity.

People say they no longer have a Houma, when they lose sight and contact of neighbours who had been part of their lives (Grangaud, 2009), or when they move out and cannot recreate a Houma in their new place of residence because of weak or lack of social relations, and not because they are homeless.

El Houma is a socio-spatial concept characterised by strong social relations between residents and the space in which these relations take place; its boundaries fluctuate with the intensity of social interactions (Grangaud, 20I3; Gentz and kramer, 2006). Its physical construct is a support for local socio-cultural practices and social interactions, 
while for its social construct, is a community that groups people around a common identity creating a sense of solidarity and belonging to El Houma (Bouaouina, 2007; Grangaud, 2009). El Houma is composed of public and private spaces; the distinction lies in the type of activities performed in the built spaces creating a hierarchy of spaces and privacy, which is important in the culture and urban planning of Muslim countries due to its social and cultural values (Ahmed, 20I2; Bouaouina, 2006).

El Houma is a representation of the local social life through the use of urban space; it creates a sense of belonging in the residents that gives them the right to appropriate the space formally and informally. It allows the residents to practice their lifestyle and sociocultural practices such as: occupying the streets to chat, rest, play cards or dominos, play football, social meetings, gathering around houses to show support in cases of funerals or weddings, informal commerce activities, occupation of public spaces to celebrate national and religious events etc (see figure I, 2) (Dris, 2005; Gentz and kramer, 2006; Grangaud, 2009).

El Houma today is still apparent in the ottoman Medina (the Casbah) in Algiers, as people built and occupied the urban spaces according to their lifestyles. The Casbah is divided into public, semi public and private spaces, and each space is occupied differently, creating a certain organisation of urban life (BenHamouche, 2003; Grangaud, 2013; Icheboudene, 2002; Grube, 1978).

El Houma is also manifested in the old neighbourhoods of the city of Algiers - the inherited French colonial city- which is the area of investigation of this research. The neighbourhoods were designed according to the nineteen century European principles of urban planning such as regularity, proportion and symmetry for streets, boulevards, hierarchy of streets, open public spaces with vegetation and fountains, regular facades with arcades at the ground floor, soft edges, and the availability of public facilities (Icheboudene, 2002; Kobis, 2017). These design principles and services ensure the social sustainability and liveliness of the neighbourhood (Gehl, 2010), therefore, apply to el Houma as well. After the independence, the Algerians moved to occupy the inherited French colonial modern city, and because of its flexible urban structure, they were able to adapt the urban spaces to their lifestyle and socio-cultural practices (Dris, 2005). As it can be seen, the definition and features of El Houma are consistent with the definition of socially sustainable neighbourhoods and communities, whereas urban social sustainability is defined as social equity and sustainability of community (Dempsey et al., 20II; Dempsey, Brown, \& Bramley, 20I2). A socially sustainable neighbourhood consists of a viable urban social unit that aims to create a sense of community and belonging, common identity, solidarity, community stability, sense of pride, sense of place and place attachment, safety and security, social interaction, cohesion and inclusion, while responding to people's lifestyle (Dempsey et al., 2012; Ghahramanpouri et al., 20 I3; HACT, 20 I5; Hemphill et al., 2004; Vallance, Perkins and Dixon, 20I I; Yiftachael and Hedgcock, 1993).

\section{Liveliness of public spaces and urban social sustainability}

Liveliness of public spaces allow people to walk and cycle safely and comfortably, it encourages and invites people of different backgrounds, age and gender to gather and use public spaces to perform various activities promoting social interaction and social cohesion. 


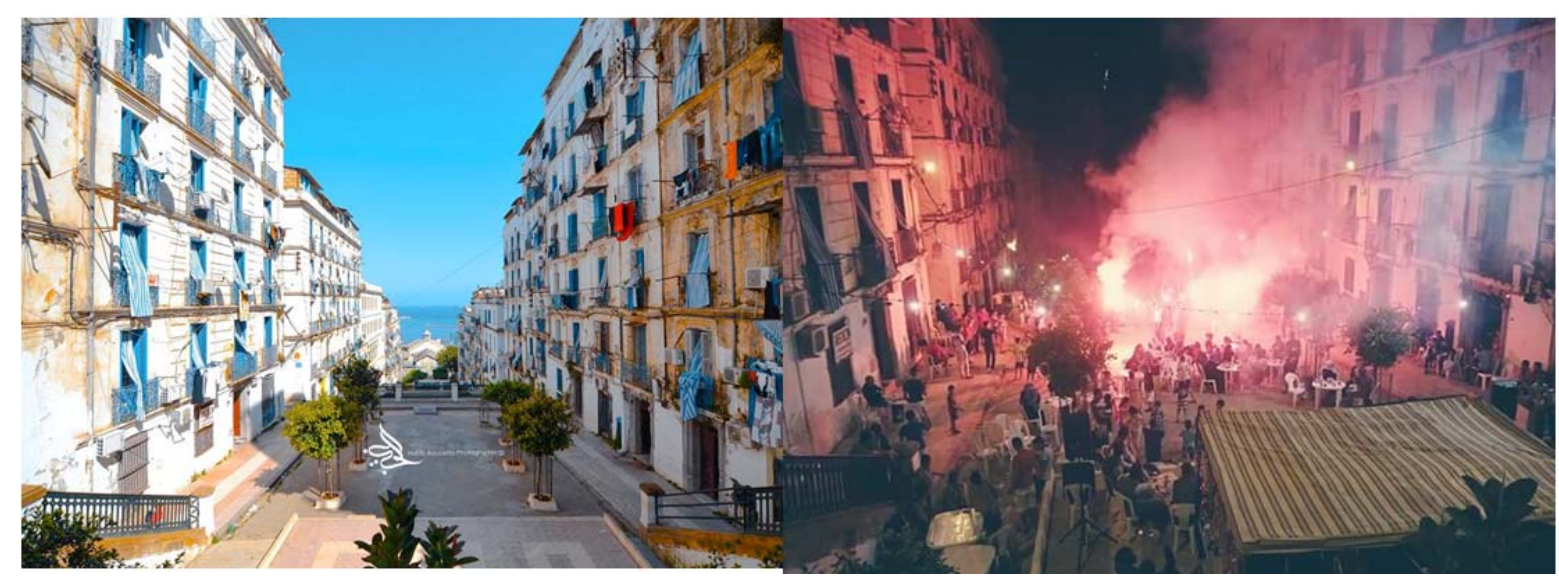

Figure I. The flexible urban structure of El Houma allows different uses of the space as shown in the picture; the public space can be used to socialise or to celebrate weddings, and other community and cultural events. Source: Habib Boucetta

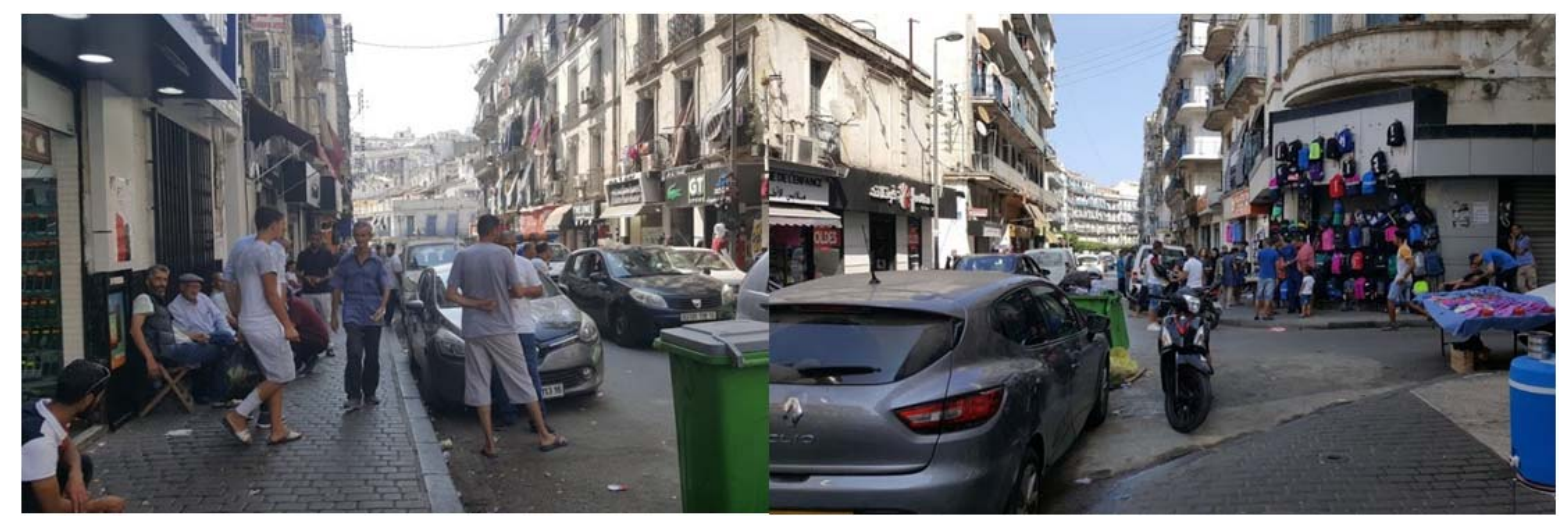

Figure 2. Left: Picture shows a gathering of people to show support for their neighbour during the day of a funeral. Right: Belonging to EL Houma gives the right to appropriate the space for informal trading, as shown in the picture Source: author.

Density and liveliness are interrelated concept; city life requires quality and quantity in terms of number of people, the design of the place and the availability of routes and local facilities. A coherent city design with compactness and reasonable population density, appropriate walking and cycling paths and good quality public spaces, increases the liveliness of an area by allowing various activities to take place. The lively city is a relative concept, the presence of few people in a narrow street indicates a lively place; a crowded place is inviting and welcoming. Conversely, large spaces make people feel lost and insecure, and they are often lifeless; similarly, tall buildings that make streets dark construct psychological barriers discouraging people from passing through (Gehl, 20l0). The ground floor of buildings is an important element of the lively city, because it is on human scale, and is the immediate field of vision where indoor and outdoor life interacts. Soft edges along the ground floor provide opportunities for people to interact with buildings and experience city life; they invite people to spend time in the streets, stop to chat, have a coffee or stare at the window shop, all of which ensure consistency of life in the street (Gehl, 20I0). 
The liveliness of public spaces in a city is fundamental to social sustainability, whereas public spaces are considered as arenas for social interaction and social cohesion. They provide a place for members of the community to coalesce, interact and perform different activities participating in the urban life, consequently, fostering sense of belonging and place attachment, as the users build relationships with the place and the people they see there frequently (Low, 2000).

\section{Social use of public spaces:}

Public spaces are considered as arenas of social interaction, they are fundamental in the social life of communities and their social value consist on providing a ground for planned and unplanned meetings between people, increasing liveliness, community cohesion and promoting people's attachment to their locality (Dines et al., 2006; Worpole \& Knox, 2007).

The availability of vegetation in public spaces contributes highly to the health and wellbeing of people. According to several studies, not only it serves as a resource for physical activity, but also helps reduce stress level, mental fatigue and mortality (Schipperijn et al., 20I0). Vegetation also cleans the air, reduces pollution, and protects from the hot sun and noise (Ritchie and Thomas, 2008).

Public spaces are places where people can display their culture, through art works, food festivals, music and song performances strengthening the identity of the place and increasing awareness of diversity (Thomas, 1991). They are considered as the nucleus of the community, creating local attachment, providing resources for socialisation and a quiet space away from the hustle of the city, a place where people can read, play cards or dominos, chat or just relax, children can play away from cars while their parents talk and create a local network of mutual support (Mehta, 20I4).

The social use of urban spaces increases levels of place attachment and sense of belonging, which in turn encourage residential stability (Ahmed, 2012; Luederitz, Lang and Von Wehrden, 20I3), as was discovered by several studies; the more people interact with their built environment through outdoor activities, the more the level of place attachment increases (Seaman \& McLaughlin, 2014).

Social interaction between people in public spaces such as streets, parks or other expressions of landscape contribute to unite communities, and grant people a common identity with the place, and vice versa (Ralph, 1976). Whereas, the quality of the place is defined and improved by the presence of people and the variety of activties (Barton, 2000).

Mehta (20I4) reviewed the literature to suggest five fundamental elements that a successful public space should have. The five criteria are inclusiveness, meaningful activities, safety, comfort and pleasurability.

Inclusiveness refers to the ability of every member of the community to access and use the public space. The social use of public spaces illustrates the level of democracy within the area, public spaces are considered as a resource for people to come together, interact, and acknowledge the presence and the diversity of each other (Arendt, 1958; Mehta, 2014). An inclusive public space is open and accessible to different members of the society and provides opportunities for various activities to happen in a safe and secure environment (Mehta, 20I4). Inclusiveness of urban spaces refers to the notion of the 'Right to the City' initiated by Henri Lefebvre (I99I) and recalled by many authors 
such as David Harvey (2003). The right to the city refers to the right for the users to re-invent and recreate the physical aspect of the city and in turn recreate themselves and the urban society.

Mitchell (2003) states that the use of urban spaces by people to fulfil their needs makes the space public. Debates on public spaces are often focused on which activities and behaviours are deemed appropriate and permitted in space, whereas, inclusiveness refer to a design that is flexible in order to accommodate various activities and behaviours of its users (Mehta, 20I4), whereas the various activities that happen in public spaces promote sociability between the users and contribute to liveliness (Gehl, 20l0) Meaningful activities refer to the multiple and diverse activities, which in turn require flexible urban spaces to accommodate them. These urban spaces are called useful spaces, because they help satisfying human needs in terms of entertainment, socialising, eating, drinking, meeting and gathering (Mehta. 20I4). Phenomenology studies suggest that these spaces encourage repeated visits and increase the recurrent use of the space, which in turn generate a familiarity with the space, creating a sense of place and place attachment (Jacobs, 196I; Seamon, 1980).

Moreover, safety is the most important aspect of public spaces, whereas lack of safety reduces significantly the liveliness of public spaces no matter how sophisticated the spaces are. Alternatively, safety promotes a constant presence of people and vice versa (Newman 1972). Safety can be achieved through maintenance of the space, presence of people of different genders, age and ethnic background, variety of activities, availability of facilities nearby, the presence of streetlights and private planting (Perkins, Meeks, and Taylor 1992; Perkins et al. 1993).

Additionally, comfort in public spaces is relevant to numerous factors, such as safety, familiarity with the people and the space, the physical condition of the place, the weather and so on, all of which promotes outdoor activities (Bosselmann et al. 1984). Pleasurability is related to imageability; spaces are pleasurable when they have a high level of spatial quality, and a recognizable image of the area. In the work on how people navigate the city, Lynch (1960) discovered that people have a mental image of their city, and the places with high imageability are the most comfortable and pleasurable.

The success of public spaces does not solely rest on the architect or the urban designer; it is also achieved by the presence and behaviour of people using and managing the space. People make places more than places make people (Worpole \& Knox, 2007).

\section{People make places: placemaking of public spaces}

"Cities have the capability of providing something for everybody, only because, and only when, they are created by everybody"

Jane Jacobs (196I)

Placemaking as a concept has gained attention after it became obvious that urban design should consider the cultural, social, economic, political and spatial aspects as well as people's perception of the urban space, people's behaviour and ways of use of urban spaces (Carmona et al., 2010). Placemaking is a collaborative process of re-shaping and revitalising public spaces by members of the community, in order to create better urban spaces. This process promotes solidarity and common identity between people and the 
place they share, enhance the physical, cultural and social identities of the place (PPS, 20I0).

Placemaking contributes to the social sustainability of the neighbourhoods, whereas it fosters social interaction in a shared space, and social network within the community by encouraging participation in community activities and increasing sense of community (Dixon \& Woodcraft, 2013). Placemaking also promotes significantly sense of belonging and a sense of place, as the transformed public space is a result of the imagination, interaction and work of people (Kohon, 20l8). It is also vital for well-being, safety and security of the place, it creates a unique identity of the place shared between people of common identity (Aravot, 2002).

Placemaking aims at creating successful urban spaces that are responsive to people's lifestyles and expectations, they are shaped by the residents according to their aspirations and shared interest. Successful urban spaces as was stated in the previous sections, should be inclusive, safe, comfortable, and provide opportunities for various activities and satisfy human daily needs.

Placemaking is not new; ground-breaking ideas were introduced in 1960s by Jane Jacobs, William H. Whyte, and Jan Gehl in 1970s, in order to design cities for people, focusing on the social and cultural aspects and the liveliness of neighbourhoods and public spaces. They encouraged designers to design spaces for the users in order to take ownership of the public spaces through performing different activities creating vibrant public life (PPS, 2007). This research built the methodology upon their methods and techniques in order to study the social use of urban space in a square in El Houma.

\section{Case study: a general profile of the neighbourhood}

Algeria is a country located in North Africa, between Morocco and Tunisia; it is the largest country in Africa and is situated on the Mediterranean Sea. Because of its strategic location, the country housed many civilisations as it was exposed to several invasions and colonisations, all of which shaped its culture and built environment (Saoudi \& Belakehal, 20I8).

The capital of the country is Algiers. It is the most populated city and it is located North, opening up on the Mediterranean Sea. Algiers was founded by the Phoenicians in I $200 \mathrm{BC}$, then in 944, the Berber Bologhine Ibn Ziri erected the city of El- Djezair (Algiers), which then evolved under the Ottoman Empire from 1516 until $19^{\text {th }}$ century, becoming what is today known as the Casbah or the ottoman Medina. In 1830, Algeria was colonised by France, and a new urban renewal plan was introduced in order to modernise and civilise the city; to change its status of an Arab/Muslim city by building a European city. The planning of the new neighbourhoods was based on the nineteen century European principles of urban planning; regularity, proportion and symmetry for streets, boulevards, hierarchy of streets, open public spaces with vegetation and fountains, regular facades with arcades at the ground floor, soft edges, and the availability of public facilities (Grabar, 2013; Icheboudene, 2002; Kobis, 20I7).

Following the independence in 1962, the Algerian population repossessed Algiers, and adapted the new built environment to their socio-cultural life recreating the concept of El Houma through social use of urban space, social interaction, and participation in community activities as an expression of placemaking (Bouaouina, 2007). 
The case study area is a neighbourhood called "Bab El Oued" located in Algiers, in an area of I.2I km², and a population of 68,364 (Wilaya of Algiers, 2016). It is a neighbourhood built during the French colonisation, and it is based on $19^{\text {th }}$ European urban planning, as it is clear from its homogenous facades of the apartment buildings, the availability of public spaces, and large boulevards and avenues facing the Mediterranean Sea.

The neighbourhood is known for the strong social relations and social cohesion between the residents; sociologists relate this to the social homogeneity of the inhabitants, and to the fact of living together in area while sharing the same space for various outdoor activities. It is a compact mixed-use neighbourhood known for its lively public spaces, be it the main streets, plazas or parks. This research studies the liveliness of a square within the neighbourhood, to demonstrate how social use of urban spaces contributes to liveliness.

\section{Social use of space: analysis and discussion}

Taleb Abderahmane square: placemaking process

The square is located in the centre of the neighbourhood, surrounded by mixed-use buildings and streets and separated from the sea front by a vehicular street (see figure3). The square fits well with the surrounding physical design; adapted to the slightly hilly site, it allows visual accessibility and offers panoramic views over the Mediterranean Sea. It also allows physical accessibility through a permeable layout, while providing a resource for various activities of the community. The mixed-use streets that surround the square, offer a variety of functions that contribute to the liveliness of the square namely: restaurant, cafes, ice cream shops, boutiques and a nearby local market. The square successfully delivers social benefits to the neighbourhood, as it is considered as a gathering point -a third place- for the residents and the passers-by. It houses a great variety of activities, age and gender. It contributes to the urban outdoor comfort, being equipped with benches for people to sit, trees, grass, and fountain to provide comfortable microclimatic conditions through shade and natural ventilation.

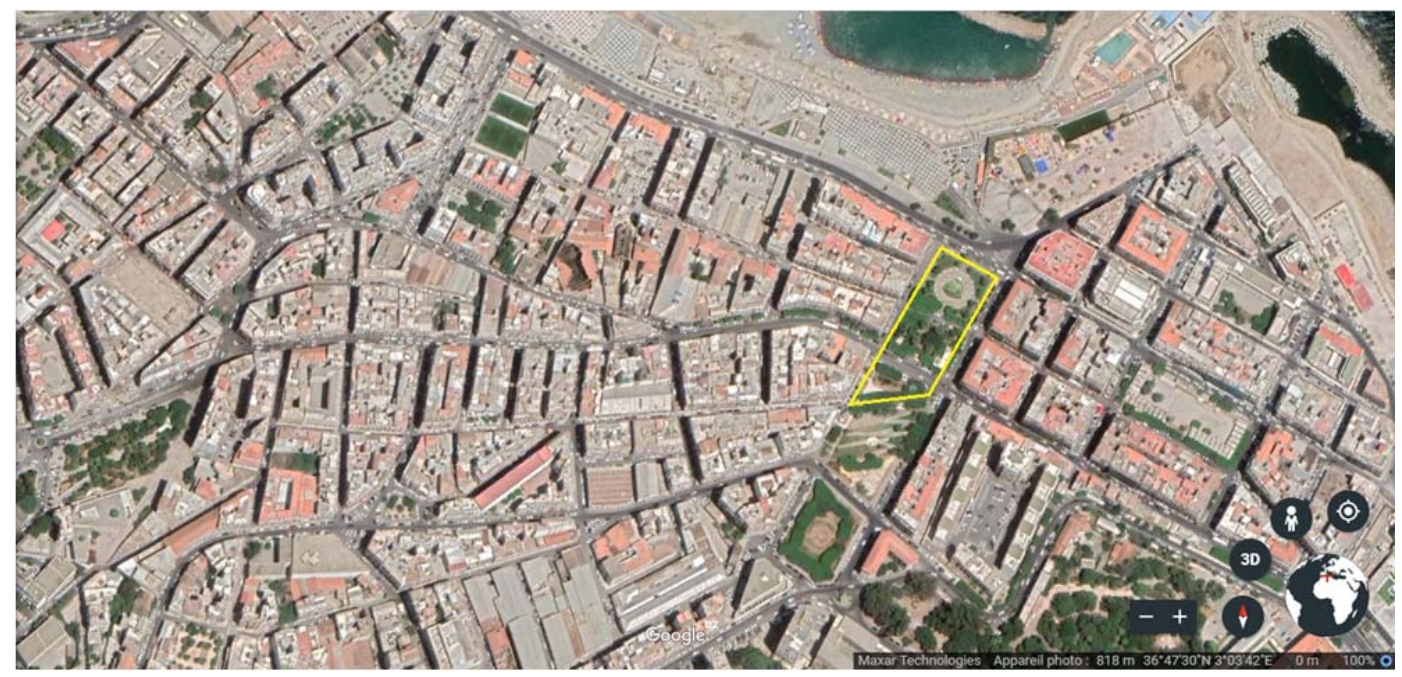

Figure 3. Location of Taleb Abderahmane square within the neighbourhood and the area studied 


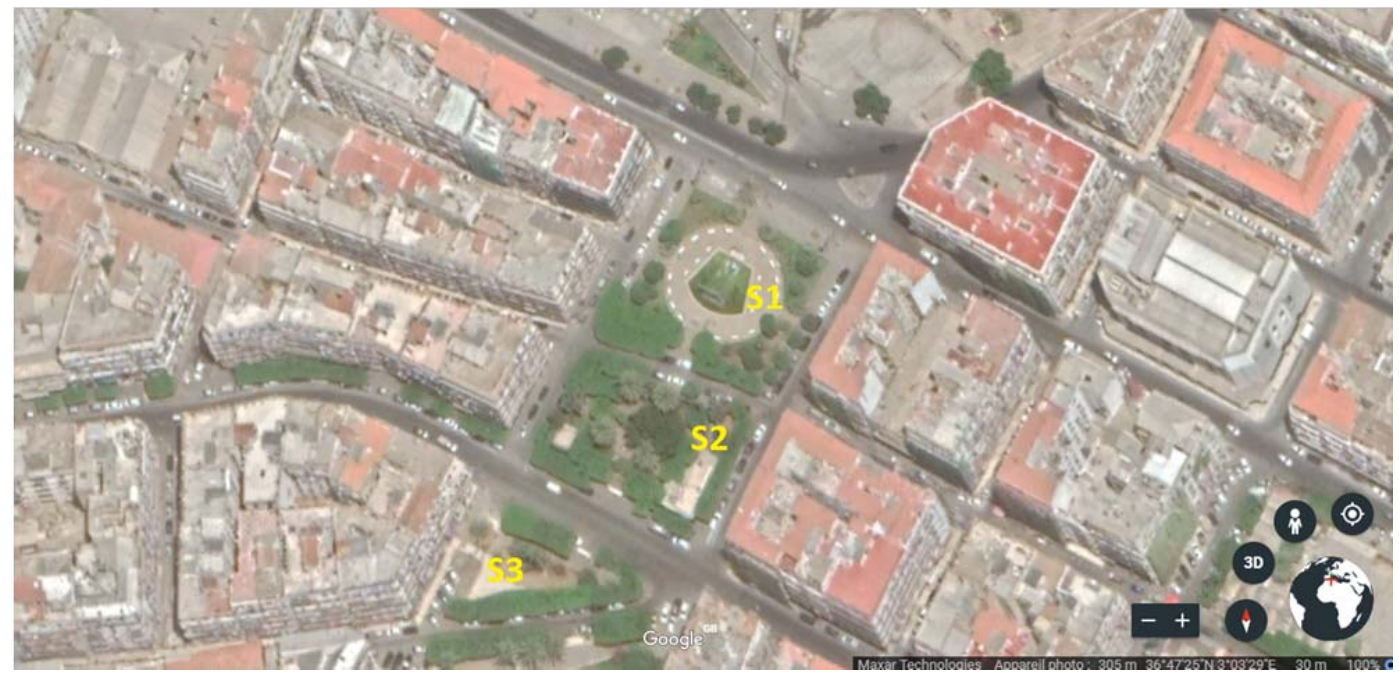

Figure 4. The three parts of Taleb Abderahmane square studied in this research

Table l: distribution of all the outdoor activities in the square

\begin{tabular}{|c|c|c|c|c|c|c|c|c|c|}
\hline \multicolumn{10}{|c|}{ Taleb Abderahmane Square } \\
\hline & SI & & & S2 & & & S3 & & \\
\hline $\begin{array}{l}\text { Type of } \\
\text { activities }\end{array}$ & All & $\begin{array}{l}\text { Weekda } \\
y\end{array}$ & Weekend & All & $\begin{array}{l}\text { Weekda } \\
\text { y }\end{array}$ & Weekend & All & $\begin{array}{l}\text { Weekda } \\
y\end{array}$ & $\begin{array}{l}\text { weeken } \\
\text { d }\end{array}$ \\
\hline $\begin{array}{l}\text { Sell food / } \\
\text { fruits }\end{array}$ & 6 & 4 & 2 & 10 & 7 & 3 & 8 & 4 & 4 \\
\hline Sell products & & & & 18 & 8 & 10 & 16 & 12 & 4 \\
\hline Rest & 581 & 381 & 200 & 309 & 189 & 120 & 129 & 79 & 50 \\
\hline Talk/chat & 106 & 36 & 70 & 94 & 42 & 52 & 52 & 16 & 36 \\
\hline Lay down & 38 & 14 & 24 & 14 & 6 & 8 & & & \\
\hline $\begin{array}{l}\text { Kids play } \\
\text { football }\end{array}$ & 13 & 4 & 9 & & & & & & \\
\hline $\begin{array}{l}\text { Kids play } \\
\text { marbles }\end{array}$ & 29 & 18 & II & 26 & 17 & 9 & 14 & 4 & 10 \\
\hline $\begin{array}{l}\text { Kids play/ } \\
\text { running } \\
\text { around }\end{array}$ & 53 & 38 & 15 & 13 & 8 & 5 & 7 & & 5 \\
\hline $\begin{array}{l}\text { People play } \\
\text { cards/domino } \\
\text { s }\end{array}$ & & & & 106 & 56 & 50 & & & \\
\hline Reading & 25 & 17 & 8 & 38 & 26 & 12 & 8 & 4 & 4 \\
\hline $\begin{array}{l}\text { Eating / } \\
\text { drinking }\end{array}$ & 47 & 32 & 15 & 25 & 19 & 6 & 9 & I & 8 \\
\hline Taking photos & 14 & 8 & 6 & & & & & & \\
\hline Cleaning & 6 & 4 & 2 & 3 & I & 2 & 2 & I & I \\
\hline Gardening & 2 & 2 & 0 & 3 & 3 & 0 & & & \\
\hline $\begin{array}{l}\text { Taking care of } \\
\text { children }\end{array}$ & 2 & 2 & 0 & & & & & & \\
\hline $\begin{array}{l}\text { Paid work/ } \\
\text { shoemaker }\end{array}$ & & & & 8 & 6 & 2 & & & \\
\hline
\end{tabular}


The placemaking in the square is illustrated through the different activities performed by the users, which increase social interaction and social cohesion, building a resilient community characterised by solidarity, trust and common identity which are needed to resist against any potential social disruptions.

The square has various stimulating elements for social activities and social interactions. First, a comfortable microclimate is provided through shade and natural ventilation by means of trees, grass and fountain. Second, benches offer a place for people to sit, rest, read, eat or play cards. Third, the consistent presence of people in the square sends a sign of safety and security and invites people to join.

Table I shows the number of all the outdoor activities in the different parts of the square. The highlighted ones are the social activities used for the analysis.

Although the square is accessible by everyone, it is divided into three areas based on the types of activities that occur in each part, and their implications with the urban design, furniture and users. The park is divided into three parts (SI, S2, S3), and separated by vehicular streets; each part has a different meaning to people, informed by the furniture, the categories of people and the type of activities that take place in it (see figures $4,5,6)$. The lower part of the square (SI), where the fountain is centrally located, has unobstructed views towards the sea and the streets around it. It is an open space that sends a sign of safety unlike enclosed spaces, which look private and unwelcoming. Thus, it is used by people of different gender and age. Families usually gather in this open space, where there is more space for their children to run around play and interact with the fountain, children also play ball games and marbles games in the earthen parts around the trees and the grass (see figure 5).
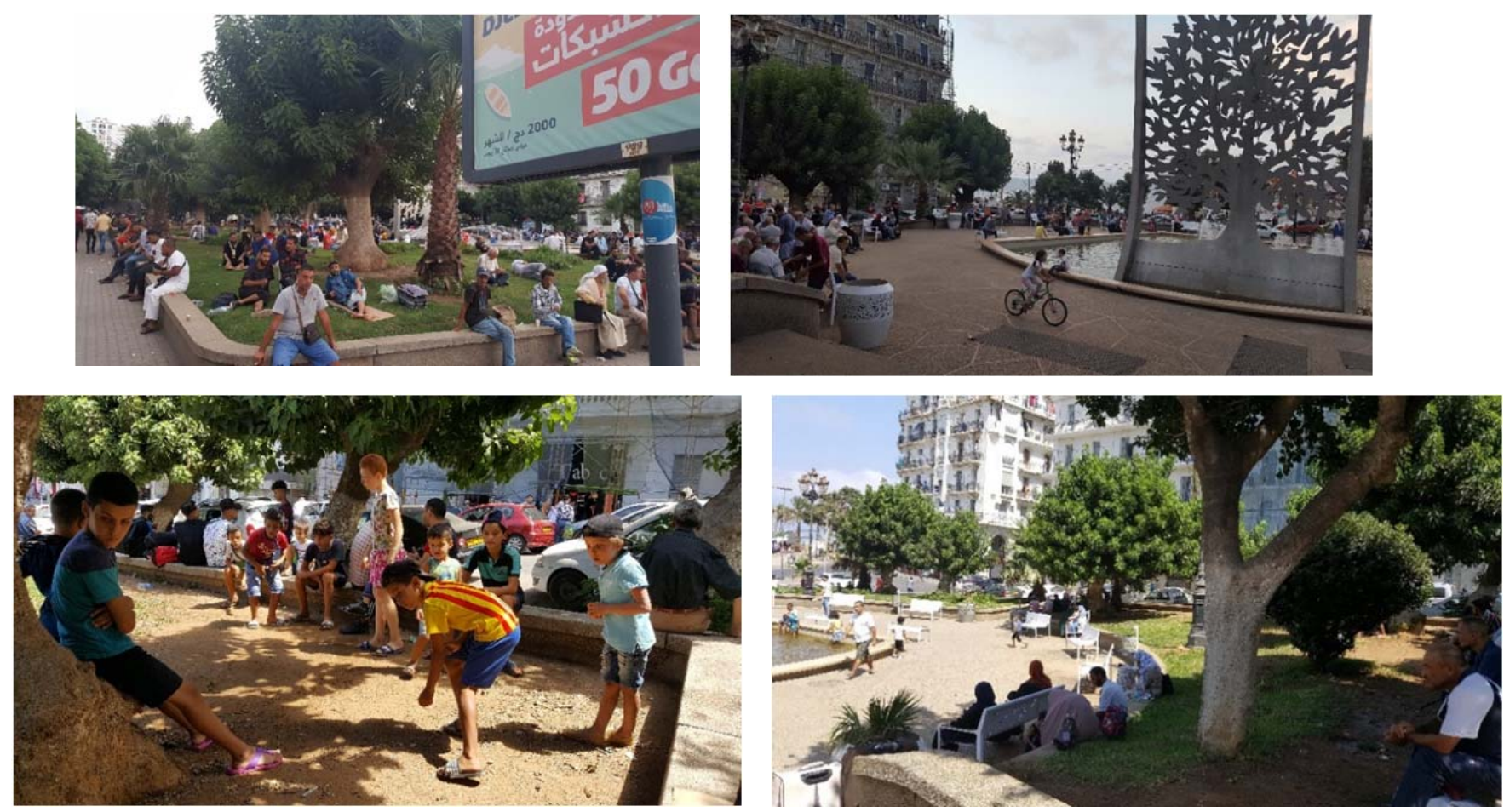

Figure 5. Different activities performed in Part SI of the square (chatting, resting, laying down, playing, eating and drinking...) 
The presence of children increases the vitality of the area, as Gehl (2010) stated; when children see other children play, they hurry to join them. Kids from the neighbourhood come to play in this square, as it is rare to find an open space with earth and grass where marbles games can take place, hence this square is considered as a place that groups children of the neighbourhood to play and share experiences together, increasing social relations between them, which is important in El Houma. In El Houma, relationships between neighbours are as strong as family ties, because neighbours usually study together, play together and hang out together, with time a sense of community, common identity and trust grow in them and last forever.

The activities of eating and drinking are also common; people can buy food from the restaurants in the surrounding streets, and then sit on benches or on the grass to eat while enjoying public life. The availability of trees attracts people to sit, rest, chat or read a newspaper, whereas in the lower part of the space, people lay down under trees enjoying the fresh breezes coming from the sea.

In S2, the central part of the square, the main activity is playing cards/dominos, it is occupied mainly by mature and old people, who sit there comfortably during summer time and during different periods of the day, benefitting from shade, and enjoying the company (see figure6). The benches are made of wood, and flexible enough to be adapted to the needs of people; the availability of two seats facing each other allows four people to sit in front of each other. In addition, a removal of the backrest frees the obstruction and allows people to face each other to play cards or dominos. Unlike the benches in the lower part of the square SI, they are made of metal as one element that cannot be modified, so people who play games that require four players facing each other prefer to use the square S2.

In a conversation with some users of this part of the square, which are residents or exresidents of the neighbourhood, the author sensed a high level of place attachment and sense of belonging with the area by the users. People spend almost their entire day in the space, playing dominos, chatting or reading a newspaper some of them even take naps in the grass under trees. Some of the users, who grew up in the neighbourhood, had relocated in other neighbourhoods, but they still come to their Houma every day to take part in the urban life that was part of their daily life for many years. These users consider this place as their Houma, and their new houses as dormitories. They come to the neighbourhood in the morning, spend their whole day there and return to their house in late afternoon. They are used to the urban life, lifestyle, architecture and urban characteristics of the place, and most importantly, they still have strong social ties with members of el Houma with whom they shared life and experiences together. It was also pointed out to the author, that this place is also crowded in winter, when it rains; people gather in the arcades of the surrounding buildings seeking shelter from the rain, and after the rain stops, they get back to play dominos. According to the interviewees, there is a need for a tent or a structure that protect people from the rain, because this is the only leisure activity that old people have in the area, they unfortunately do not benefit from organised excursions or other activities.

As a sign of placemaking, users of the space adapted the benches to their needs seeking comfort and practicality, however, as this space is only used by people who play dominos, they expressed their desire to have chairs and tables ready to play on, rather than transforming a bench into a table. They also asked for comfortable seats, as the users of this space are mainly old, therefore comfort is essential for them. The author 
also found out that young people usually socialise in the main streets, participating in a different urban life, Hence, users of this part (S2) feel identified with the place, and grant themselves the right to use any benches or space within this part freely. Whereas during the observations, the author witnessed a bunch of mature/old people asking a group of youth, who were just sitting and doing nothing to free up a bench for them so they can play their game. They asked them nicely for the bench: "if you are going just to sit here, it is better to sit somewhere else and let us use this bench, because we want to play dominos".

Informal commerce activities are not present inside the square; however, they are present on the main street that separates S2 and S3, where people sell fruits, toys, clothes or books, aiming for passers.

The space S3, is small and has a hilly triangular shape, it is usually empty because it lacks trees and maintenance. Consequently, fewer activities take place in this space comparing to the other two spaces, which is noticed by the degree of liveliness of the area (see figure 7).

The side of the space S3 that faces the main street offers shaded sitting areas, where people sit there to chat, eat or read a newspaper while waiting for transport, or watching urban life. The upper part leads to a semi-public street, which is usually quiet and occupied by residents of the area. This part of the square is usually occupied by people, who want to have a conversation in a quiet place, sitting on the few benches that exist.
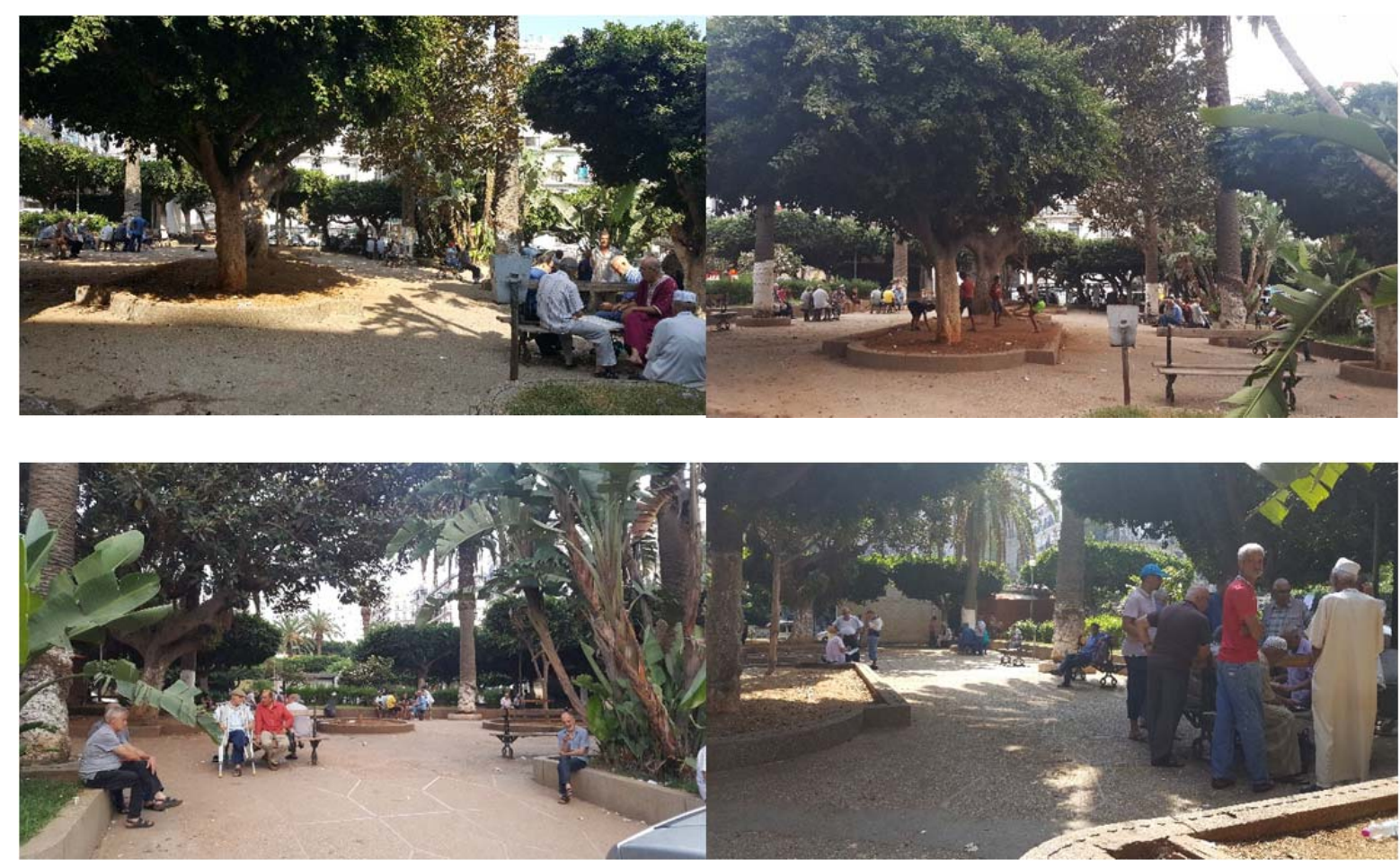

Figure 6. activities performed in part S2 of the square (chatting, resting, drinking, playing marbles, playing dominos...) Source: Author 
Overall, the temporal pattern of activities varies during the day; there is a fluctuation of activity intensity overtime. The number of activities is quite low in the early morning, but during the afternoon, the intensity of activities remarkably increases. During the weekend and especially on Friday, when most people do not work, the intensity of social activities increases reaching its zenith and the square becomes very crowded. Various activities take place; they are about double or more than in the other days and last longer and this pattern persists from the afternoon until the evening. The lights are only provided in SI, where families usually hang out, and children play and interact with the fountain, thus, the space is lively in the evening because it is perceived safe and welcoming. Unlike, S2 and S3, which are unilluminated at night, hence they are empty or occupied by homeless or young people (see figure 8).

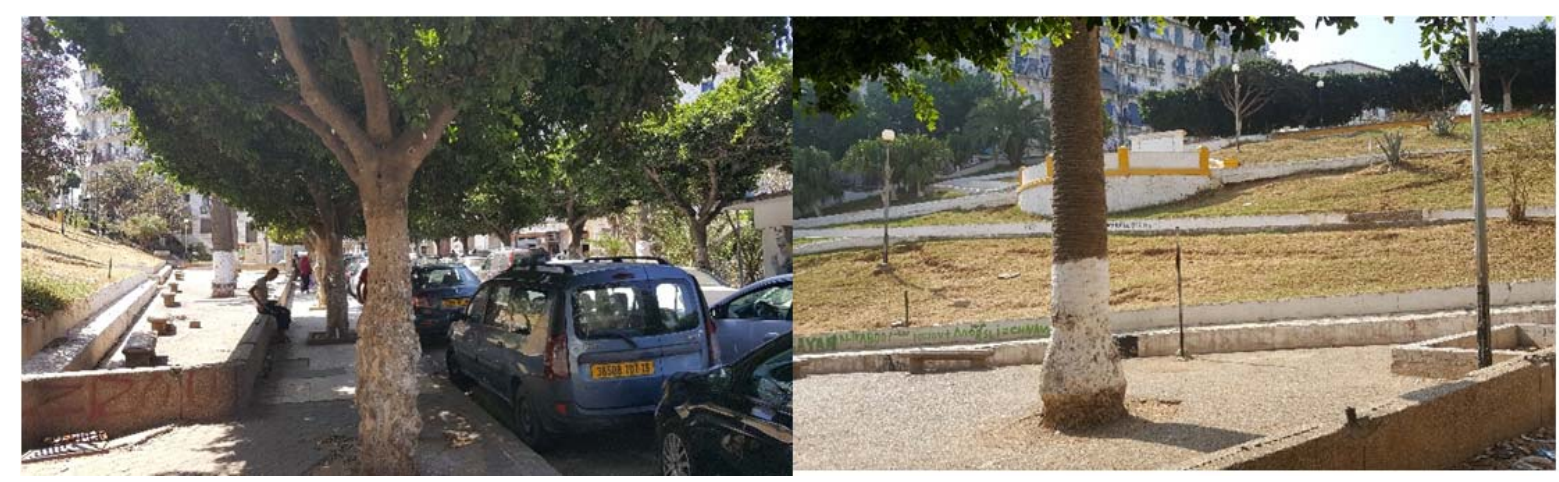

Figure 7. Lack of activities performed in part S3 of the square due to the poor quality of the space. Source: Author

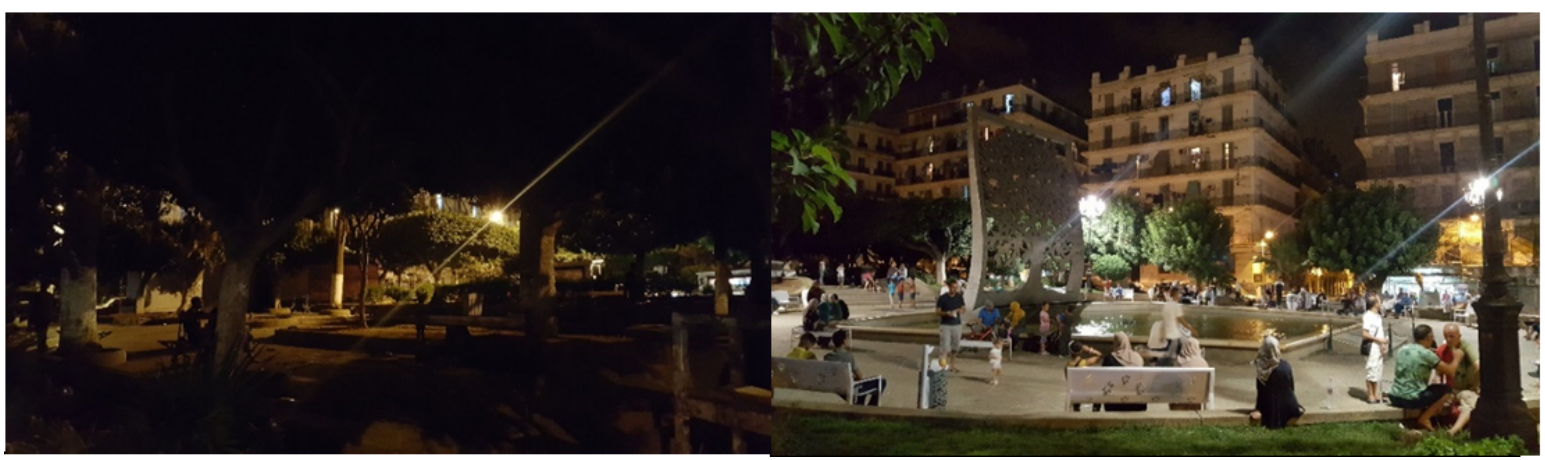

Figure 8. (left:) the space S2 lacks lights, is empty and lifeless; (right): space SI, is lit, lively and safe

\section{Conclusion}

'Cultures and climate differ all over the world, but people are the same. They will gather in public if you give them a good place to do it.' (Gehl, 2010, cited in Matan \& Newman, 2016: 40)

It is important to acknowledge the various activities that happen in public spaces, which can inform the design of future projects to be responsive to people's needs and aspirations, as the notion of sustainability advocates. In order to design cities for people, it is fundamental to apply a human perspective, through observing and analysing people's 
behaviour in public spaces. Understanding people's lifestyle will help create spaces that are responsive to the social needs of residents and ensure the liveliness of the urban spaces.

The examined case study showed how the features of the place plus the presence of people define the liveliness of the area and in turn contribute to urban social sustainability. The observations of the social activities during different days of the week and during different times of the day demonstrated how frequent the space is used, and which activities are ubiquitous in the space. Additionally, the unstructured interviews helped gain an insight on how members of El Houma feel about the space.

The characteristics of the square are fundamental in grouping people and allowing them to express themselves through the various and multiple activities, the availability of vegetation provided comfort and shelter from the undesirable climate conditions and the availability of the fountain made the space active.

The design of the lower part of the square SI as an open public space with unobstructed views ensured the consistent presence of families and children. The presence of different categories of people in the square performing various activities made the square inclusive, safe, comfortable and useful, all of which increase liveliness and community cohesion. Unlike $S 2$ which is used mainly by mature and old people performing at most three activities- reading, resting but mainly playing dominos-, the presence of one category of people and one type of activity limit the inclusiveness of the space, and make the space poor in terms of diversity and complexity, it is true that the space is lively but it lacks diversity and discourage other people from visiting the space as it does not satisfy their needs.

The analysis of the square in El Houma proved how placemaking as a people-centred approach can enhance the liveliness of the area. The observations of the social activities provided an overview of how well the square is responsive to people's needs and aspirations, the presence of people in the square and during different times of the day is relevant to many parameters; like weather conditions, design of the space, day of the week, category of people, urban furniture and types of activity.

The square SI, is very lively during the day and at night as well, thanks to its flexible design which allows various activities to take place; the large area around the fountain allowed the kids to run around, play football, or even ride a bike, while their parents sitting on the benches in front them. The presence of kids sends signs of safety and invites other children to join, thus increase the liveliness. The parents can rest on the benches or the grass around and start a conversation with other visitors of the square, and at the same time watch over their kids, all of which help create social relations between people.

It was noticed that the vegetation in the square contributes highly to the liveliness of the area through providing comfort, as it enables children to play marble games and provide people with a shelter from the hot sun and hustle of the vehicular streets. People sit under the trees or lay down in the grass while enjoying the view and the fresh breezes coming from the sea.

A strong sense of belonging in the residents was sensed during the observations, accordingly the residents felt the right to customise the space and its use according to their needs. For instance, the part S2 of the square is used by people who have been part of El Houma for a while and feel identified with the area, so they appropriated the space according to their needs. Benches were modified to suit their aspirations to 
perform the dominant activity in the space which is "playing domino". Being part of el Houma not only created a strong sense of community but also place attachment, as the users of square still visit the area despite being relocated to another neighbourhood, therefore, placemaking and liveliness of the square are important elements that highly fostered the sense of community and social sustainability in the area.

The availability of lights in the evening creates a sense of safety and maintains the liveliness of SI, unlike the other two parts of the square. The upper part of the square S3 is rarely used due to the lack of maintenance, vegetation and urban furniture, and being unilluminated at night.

As was demonstrated through this research, social use of urban spaces as a way of placemaking can reinforce sense of community and social cohesion, whereas placemaking as collaborative process allows the community to re-imagine and re-make its public spaces according to their needs. It contributes to the liveliness of public spaces; it enhances their image and inclusiveness, and allows people to participate in community activities, strengthening their sense of community and place attachment. A successful public space is inclusive, safe, comfortable, attractive and lively. It serves as the heart of the community, it groups people in a common place, where they can interact, participate in urban life, and acknowledge the diversity and existence of each other, and it strengthens the identity of the place by allowing cultural activities to take place.

In a hot city like Algiers, people tend to seek shade and comfortable spaces while spending time outdoors. Spaces that are mostly used by people are the ones covered by trees. Urban furniture has also an important role in achieving liveliness, as was demonstrated in the previous sections, people tend to use seats that are suitable for their needs or transform them according to their activities. Safety and security are fundamental in attracting people from different background, gender and age to participate in urban life.

\section{References}

Abu-Lughod, J. L. (1987). The Islamic City - Historic Myth, Islamic Essence and Contemporary Relevance. International Journal of Middle East Studies, 19(2), I55-176.

Ahmed, K. G. (2012). Urban Social Sustainability: A Study of the Emirati Local Communities in Al Ain. Journal of Urbanism, 5(I), 4I-66. https://doi.org//0.1080/I7549I75.20I2.6595I5.

Aravot, I. (2002). Back to Phenomenological Placemaking. Journal of Urban Design, 7(2), 20I212.

Arendt, H. (1958) The Human Condition. Chicago, IL: University of Chicago Press.

Barton, H. (2000). Sustainable communities: the potential for eco-neighbourhoods. London. Earthscan publication LTD.

Benhamouche, M. (2003). Decision-making system and urban geometry in traditional Muslim cities: the case of Algiers 1516- 1830. Journal of architecture and planning research. PP 308.

Bosselmann, P., J. Flores, W. Gray, T. Priestley, R. Anderson, E. Arens, P. Dowty, S. So, and J.

Kim. 1984. Sun, Wind and Comfort: A Study of Open Spaces and Sidewalks in Four Downtown Areas. Berkeley: Institute of Urban and Regional Development, College of Environmental Design, University of California. 
Bouaouina, N. 2006. Les formes de sociabilité urbaine dans l'espace public et privé de l'habitat maghrébin : cas de la ville d'Alger. In Pierre-Wilfrid Boudreault (ed). Génies des Lieux: Enchevêtrement Culturel, Clivages et Réinventions du sujet collectif. Presses de l'université du Québec.

Bouaouina, N. (2007). Alger à travers sa « houma »: Formation et déformation des espaces identitaires communautaires de quartier. Esprit Critique, I0(I), I-16. Retrieved from http://www.espritcritique.fr/Dossiers/dossier.asp?idcode $=66$.

Briggs, X. de S. (1997). Moving up versus moving out: Neighborhood effects in housing mobility programs. Housing Policy Debate, 8(I), 195-234. https://doi.org//0.1080/105I I482.1997.952 I 252.

Burckhardt, T. (2009). Art of Islam: Language and Meaning. Library of Congress Cataloging-inPublication Data.

Carmona, M., Tiesdell, S., Heath, T. \& Oc, T., Public Places Urban Spaces, Oxford: Architectural Press, 2010.

Choguill, C. L. (2008). Developing sustainable neighbourhoods. Habitat International, 32(I), 4I-48. https://doi.org// 0.1016/j.habitatint.2007.06.007

Dempsey, N., Brown, C., \& Bramley, G. (2012). The key to sustainable urban development in UK cities? The influence of density on social sustainability. Progress in Planning, 77(3), 89-|4I. https://doi.org/I0.1016/j.progress.2012.01.00I

Dempsey, Nicola, Bramley, G., Sinead, P., \& Brown, C. (201 I). The Social Dimension of Sustainable Development: Defining Urban Social Sustainability. Sustainable Development, 19, 289-300. https://doi.org//0.1002/sd

Dickie, J. (1994). Granada: a case study of arab urbanism in Muslim Spain. In Jayyusi, S,K. \& Marin, M. (2nd ed) The Legacy of Muslim Spain. E. J. BRILL

Dines, N. Cattell, V. Gesler, Wil, \& Curtis, S (2006). Public spaces, social relations and wellbeing in East London. The Policy Press for the Joseph Rowntree Foundation. Available through www.jrf.org.uk

Dixon, T., \& Woodcraft, S. (20I3). Creating strong communities: measuring social sustainability in new housing development. Town and Country Planning Journal, (November), 473-480.

Dris, N. (2005). Urban forms, meanings and representations: the interference of models. Espaces et Societes, (I22).

Fatani, K., Mohamed, M., \& Al-Khateeb, S. (20I7). Sustainable Socio-cultural Guidelines for Neighborhood Design in Jeddah. Procedia Environmental Sciences, 37, 584-593. https://doi.org/10.1016/j.proenv.2017.03.045

Forrest, R., \& Kearns, A. (200I). Social cohesion, social capital and the neighbourhood. Urban Studies, 38(I2), 2I25-2 I43. https://doi.org//0.1080/00420980 I 2008708 I

Francis, M. (1984). Mapping Downtown Activity. Journal of Architectural and Planning Research, I(I), 2 I-35. https://doi.org/I0.2307/4302867I 
Galster, G. C. (200I). On the Nature of Neighbourhood. Urban Studies, 38(|2), 2 I I I-2 I 24. https://doi.org// 0.1080/00420980I 20087072

Gehl, J. (1987) Life between Buildings: Using Public Space. New York: Van Nostrand Reinhold

Gehl, J. (2010). Cities for People. Washington D.C: Island Press

Gehl, J and Savarre, B. (20I3) How to study public life. Island Press

Gentz, N. Kramer, S. 2006. Globalization, Cultural Identities, and Media Representations. State university of New York Press

Ghahramanpouri, A., Lamit, H., \& Sedaghatnia, S. (20I3). Urban social sustainability trends in research literature. Asian Social Science, 9(4), I 85-193. https://doi.org/I 0.5539/ass.v9n4p I85

Grabar, H. S. (2013). Reclaiming the city: Changing urban meaning in Algiers after 1962. Cultural Geographies, 2 I (3), 389-409. https://doi.org//0.1 I77//4744740/350636 I

Grangaud, I. (2009) Masking and unmasking the historic quarters of Algiers: the reassessment of an archive. In Celik, Z. Clancy-Smith, J,A. \& Terpak, F. (Ed). Walls of Algiers: Narratives of the City Through Text and Image. University of Washington Press

Grangaud, I. (20I3). The Hawma : the processes of disqualification of an Ottoman institution ( Algiers 1830 ). Insaniyat / إنسانيات, I-I8.

Groat, L. and Wang, D. (2002) Architectural research methods. New York, US: John Wiley \& Sons, Inc

Grube, E, J. (1978). Architecture of the Islamic World: Its History and Social Meaning. in Michell, G. (ed). London: Thames \& Hudson.

HACT (20I5). Social sustainability: A white paper for your housing group. ideas and innovation in housing.

Hallman, h. w. (1984), Neighbourhoods: Their Place in Urban Life, Beverly Hills, CA, Sage Publications.

Hemphill, L., Berry, J., \& McGreal, S. (2004). An indicator-based approach to measuring sustainable urban regeneration performance: Part I, conceptual foundations and methodological framework. Urban Studies, 4I (4), 725-755. https://doi.org/I 0.1080/0042098042000I94089

Icheboudene, L. (2002). De la houma à la cité: une evolution historique de l'espace Algerois. Revue Algerienne Des Sciences Juridiques, Economiques et Politiques, (40).

Jacobs, J. (196I). The death and life of great American cities. New York: Random House.

Jenks, M., \& Dempsey, N. (2007). Defining the neighbourhood. Town Planning Review, 78(2), I53178. https://doi.org// 0.3828/tpr.78.2.4

Kobis, R. (2017). al-Madinah or la ville? An architectural \& urban " clash of civilizations " - the example of the city of Algiers. Urban Development Issues, 54, 27-34. https://doi.org/I0.15I5/udi-2017-0009

Kohon, J. (2018). Social inclusion in the sustainable neighborhood? Idealism of urban social sustainability theory complicated by realities of community planning practice. City, Culture and Society, I5(August), 14-22. https://doi.org//0.1016/j.ccs.2018.08.005 
Komeily, A., \& Srinivasan, R. S. (2015). A need for balanced approach to neighborhood sustainability assessments: A critical review and analysis. Sustainable Cities and Society, 18, 32-43. https://doi.org/I0.1016/j.scs.2015.05.004

Lefebvre, $\mathrm{H}$ (199I) The Production ofSpace. Blackwell, Oxford

Lofland, L. 1998. The Public Realm: Exploring the City's Quintessential Social Territory. New York: Aldine De Gruyter.

Low, S. 2000. On the Plaza: The Politics of Public Space and Culture. Austin: University of Texas Press.

Luederitz, C., Lang, D. J., \& Von Wehrden, H. (2013). A systematic review of guiding principles for sustainable urban neighborhood development. Landscape and Urban Planning, II8, 40-52. https://doi.org/I0.1016/j.landurbplan.2013.06.002

Lynch, K. 1960. The Image of the City. Cambridge, MA: MIT Press.

Mahdzar, S. S. B. S. (2008) Sociability vs Accessibility Urban Street Life. PhD thesis University College London

Mahgoub, Y. (2007). Cultural Sustainability and Identity: The Case of Kuwait. The International Journal of Environmental, Cultural, Economic and Social Sustainability, 3(I), I37-I44. https://doi.org/l 0.18848//832-2077/CGP/v03i0I/54307

Marique, A. F., \& Reiter, S. (201 I). Towards more sustainable neighbourhoods: Are good practices reproducible and extensible?: A review of a few existing "sustainable neighbourhoods." PLEA 20II Architecture and Sustainable Development, Conference Proceedings of the 27th International Conference on Passive and Low Energy Architecture, (July), 27-32. Retrieved from http://www.scopus.com/inward/record.url?eid=2-s2.084864 I I 7654\&partnerID=tZOtx3y I

McMillan, D. W., and D. M. Chavis. 1986. "Sense of Community: A Definition and Theory." Journal of Community Psychology I4 (I): 6-23.

Meegan, R., \& Mitchell, A. (200I). 'It's Not Community Round Here, It's Neighbourhood': Neighbourhood Change and Cohesion in Urban Regeneration Policies. Urban Studies, Vol. 38(12), 2167-2194.

Mehta, V. (20I4). Evaluating Public Space. Journal of Urban Design, Vol. 19, pp. 53-88. https://doi.org/I0.1080/I3574809.2013.854698

Mitchell, D. (1995). Mitchell End of Public Space? People's Park, Definitions of the Public, and Democracy. Annals of the Association of American Geographers, Vol. 85, pp. 108-133.

Mumford, L. (1937). 'What is a city?'. Architectural Record, 82, November. Mumford, L. (1954). The neighbourhood and the neighbourhood unit. Town Planning Review, 24, 250-270.

Nadarajah, M \& Yamamoto, A, T. (ed) 2007. Urban crisis: Culture and the sustainability of cities. United Nations University Press

Newman, O. 1972. Defensible Space; Crime Prevention through Urban Design. New York: McMillan 
Perkins, D. D., J. W. Meeks, and R. B. Taylor. (1992) "The Physical Environment of Street Blocks and Resident Perceptions of Crime and Disorder: Implications for Theory and Measurement." Journal of Environmental Psychology I2 (I), 2 I- 34.

Perkins, D. D., A. Wandersman, R. C. Rich, and R. B. Taylor. (1993) "The Physical Environment of Street Crime: Defensible Space, Territoriality and Incivilities." Journal of Environmental Psychology 13 (I), 29-49.

Project for Public Spaces (2007). What is placemaking? Available through https://www.pps.org/article/what-is-placemaking

Ralph, E. (1976) Place and Placeness. SAGE, London

Raymond, A. (1998). The Arab city, Aleppo, at the Ottoman era - The spatial structure of the city. Ifpo Presses, I-25.

Ritchie, A. and Thomas, R. (2008). Sustainable urban design. Taylor \& Francis.

Rohe, W. M. (2009). From local to global: One hundred years of neighborhood planning. Journal of the American Planning Association, 75(2), 209-230. https://doi.org//0.1080/0194436090275/077

Saoudi, H., \& Belakehal, A. (2018). World's urban sustainable policies and sustainability in algeria. Courrier Du Savoir, (26), 593-604.

Schipperijn, J., Stigsdotter, U. K., Randrup, T. B., \& Troelsen, J. (2010). Influences on the use of urban green space - A case study in Odense, Denmark. Urban Forestry and Urban Greening, 9(I), 25-32. https://doi.org// 0.1016/j.ufug.2009.09.002

Seamon, D. (1980) "Body-subject, Time-space Routines, and Place-ballets." In The Human Experience of Space and Place, edited by A. Buttimer, and D. Seamon, 148- 165. New York: St. Martin's Press

Seaman, J., \& McLaughlin, S. (20I4). The importance of outdoor activity and place attachment to adolescent development in Coös County, New Hampshire. Building Knowledge for Families and Communities, 208(37). Retrieved from http://scholars.unh.edu/carsey/208/

Sharifi, A. (2016). From Garden City to Eco-urbanism: The quest for sustainable neighborhood development. Sustainable Cities and Society, 20, I-16. https://doi.org/I0.1016/j.scs.2015.09.002

Shirazi, M. R. (2018). Mapping neighbourhood outdoor activities: space, time, gender and age. Journal of Urban Design, 24(5), 7/5-737. https://doi.org// 0.1080/13574809.2018.1458607

Smith, M. E. (2010). The archaeological study of neighborhoods and districts in ancient cities. Journal of Anthropological Archaeology, 29(2), 137-154. https://doi.org/10.1016/j.jaa.2010.01.00I

Sturgeon, D., Holden, M., \& Molina, A. (2016). What Does Neighborhood Theory Mean for Ecourbanism? Introduction to the Themed Issue on "Ecourbanism Worldwide." Journal of Urban Research, (14), I-14.

Suttles, G. D. (1972) The Social Construction of Communities. Chicago, IL: University of Chicago Press. 
Thomas, M. (199I) “The Demise of Public Space.” In Town Planning Responses to City Change, edited by V. Nadin, and J. Doak, 209- 224. Avebury: Aldershot.

Vallance, S., Perkins, H. C., \& Dixon, J. E. (20I I). What is social sustainability? A clarification of concepts. Geoforum, 42(3), 342-348. https://doi.org/I0.1016/j.geoforum.20I I.01.002

Von Gruenbaum, G. . (1958). The muslim town. Ekistics (Published by Athens Center of Ekistics), 6(36), I I0-I 17. Retrieved from https://www.jstor.org/stable/43620903

Wang, F. (20I7). Streets and Lanes. The Gradual Vanishing of Public Space, Public Life and Urbanity in Chinese Cities. The Planning Review, 53(2), 45-49. https://doi.org//0.1080/02513625.2017.1340557

Wehr, H. (1976). A Dictionary of Modern Written Arabic. Edited by J Milton Cowan. Spoken languages services, Inc.

Wilaya of Algiers. (2016). available through: The official website of the Wilaya of Algiers: http://www.wilaya-alger.dz/en/wilaya/

Worpole, K., \& Knox, K. (2007). The Social Value of Public Spaces. Joseph Rowntree Foundation, 15. Retrieved from https://www.jrf.org.uk/sites/default/files/jrf/migrated/files/2050-publicspace-community.pdf

Yigitcanlar, T., Kamruzzaman, M., \& Teriman, S. (20I5). Neighborhood sustainability assessment: Evaluating residential development sustainability in a developing country context. Sustainability (Switzerland), 7(3), 2570-2602. https://doi.org/l 0.3390/su7032570

Zhang, Q., Yung, E. H. K., \& Chan, E. H. W. (2018). Towards sustainable neighborhoods: Challenges and opportunities for neighborhood planning in transitional Urban China. Sustainability (Switzerland), I0(2). https://doi.org/I0.3390/su 10020406 